\title{
Protective Effect of Immature Coconut Water on Hepatocytes against Carbontetrachloride-induced Liver Damage in Wister Rats
}

\author{
Gideon Ihebuzo Ndubuka ${ }^{1}$, Wilson Chimaobi Okafor ${ }^{2}$, Ekezie Jervas ${ }^{3}$, Iwuji Samuel Chidi ${ }^{4}$, Okeke \\ Chukwubuike Udoka ${ }^{5}$, Osuchukwu Ikechukwu, Williams ${ }^{6}$ \\ ${ }^{1,2,4}$ Department of Biomedical Technology, Federal University of Technology, Owerri, Nigeria \\ ${ }^{3}$ Department of Anatomy, Federal University of Technology, Owerri, Nigeria \\ ${ }^{5,6}$ Department of Prosthetics and Orthotics, Federal University of Technology, Owerri, Nigeria
}

\begin{abstract}
The biochemical characteristics of immature coconut water (ICW) have presented it as atherapeutic agent that can be used extensively in the field of biochemistry and medicine for both industrial, and preventive, management and curative purposes. Development of a more efficient and cost effective means of prevention and management of liver disorders through antioxidant activities were the objectives for embarking on the current experiment. This experiment is aimed at investigating the protective effect of ICW against carbon tetrachloride (CCl4) induced hepatotoxicity. 20 rats were fed on standard diet and divided into four groups. Rats in group 1 and group 2 were injected intraperitoneally (i.p) with olive oil. Group 1 received tap water only, while group 2 received ICW (100ml/kg body weight/day) only. Rats in Group 3 and Group 4 were injected i.p with CCl4 (5ml/kg body weight). Group 3 received tap water, while group 4 received ICW $(100 \mathrm{ml} / \mathrm{kg}$ body weight/day) only. At the end of the experiment (1 week), blood and liver samples were collected for biochemical and histopathological analysis. The present findings revealed that, CCl4 elevated serum enzyme activities of liver and some biochemical parameters, but these effects were prevented by the prior administration ICW on rats. Histopathologically, a significant cyto-architectural distortion, hepatocyte degeneration, necrotic cells, fatty liver, and inflammatory cell migration were observed in the liver of CCl4 treated group. The present study concluded that ICW administration played a protective role against CCl4induced liver damages in Wister rats. These protective effects were in the form of improving liver enzyme activities, blood biochemical parameters and histological features of liver in CCl4-intoxicated rats. In the future, a dose dependent protective effect, and in vitro and in vivo regenerative effect of ICW on hepatocytes, could be investigated.
\end{abstract}

Keywords: Protection, Hepatocyte, Immature coconut water (ICW), Histopathology, Serum

\section{Introduction}

The liver is the largest gland and the second largest organ in the body. It weighs approximately $1500 \mathrm{~g}$ and accounts for approximately $2.5 \%$ of adult human body weight [1]. It has a complex architecture, and performs a myriad of functions in the body [2,3]. Drugs and toxins or viral infection can cause extensive damage to hepatocyte, reducing function and regeneration, and thereby leading to liver failure $[4,5]$. Liver diseases remain one of the more serious health problems [6, 7], as it accounts for it $7.9 \%$ of the total medical admissions [8] and will become the $14^{\text {th }}$ most common cause of death in 2030 [9].

Toxicity of CCl4 is a well characterized murine model for the study of oxidative damage in vivo [10], as it has been widely used for experimental induction of liver damage [1113]. $\mathrm{CCl} 4$ metabolism by the hepatic cytochrome $\mathrm{P} 450$ generates the trichloromethyl free radical, which readily interacts with molecular oxygen to form trichloromethylperoxyl radicals that are hepatotoxic [14, 15]. Hepatotoxicity of $\mathrm{CCl} 4$ can lead to cell injury and liver damage, in a similar way as what happens in the cases of acute hepatitis $[16,17]$. Thus, the effort towards the prevention of hepatic damage by eliminating free radicals and prevent lipid peroxidation, is justified. The protective effects of various natural and synthetic products against hepatotoxicity have been observed to have been reported [18-20], with varying degrees of protection.
Immature coconut water (ICW) is the liquid found inside green coconut before the coconut matures and turns acidic [21]. It contains the various vitamin B complexes[22], vitamin $\mathrm{C}(15 \mathrm{mg} / 100 \mathrm{~mL})$, and a free amino acid L-arginine $(30 \mathrm{mg} / \mathrm{dL})$, which significantly reduce lipid peroxidation [23]. It is also highly rich in Inorganic ions such as K (290 $\mathrm{mg} \%$ ), $\mathrm{Na}$ (42 $\mathrm{mg} \%), \mathrm{Mg}$ (10 mg \%), P (9.2 mg \%) etc. These Micronutrients act directly to quench free radicals by donating electrons, or indirectly as a part of metallo enzymes [24].

In this present study, we investigated the protective effects of young coconut juice against CCl4-induced liver toxicity in rats by examining serum levels of liver enzymes.

\section{Materials and Methods}

\section{Plant Materials}

Young coconuts were (Cocosnucifera L.) collected from Eziobodo Community, in Owerri-West Local Government Area of Imo State, Nigeria. It was authenticated and identified by the department of Forestry \& Wildlife, School of Agricultural Technology, Federal University of Technology, Owerri; as a dwarf (autogamous) Coconut (Cocosnucifera L. Arecaceae). The fresh YCW was obtained from the coconuts each time it is required for administration on the Wister rats. 


\section{International Journal of Science and Research (IJSR) \\ ISSN (Online): 2319-7064}

Index Copernicus Value (2013): 6.14 | Impact Factor (2014): 5.611

\section{Animal}

A total of 20 adult male Wistar rats with body weights of 175-200g obtained from Animal house of the Department of Forestry \& Wildlife, School of Agricultural Technology, Federal University of Technology, Owerri, Nigeria were used in the study. The experimental animals were housed in air-conditioned rooms at $23-25^{\circ} \mathrm{C}$, kept on a $12 \mathrm{~h} / 12 \mathrm{~h}$ light/dark cycle and had free access to standard rodent pellet diet and water ad libitum. The animals were acclimatized in the laboratory conditions for a week before the commencement of the study. The experimental procedures adopted in this study were in strict compliance with the United States National Institutes of Health Guidelines for Care and Use of Laboratory Animals in Biomedical Research (1985, no. 85-23) (25).

\section{Chemical}

Carbon tetrachloride (Riedel-de Haen AG SeelzeHannover), Olive oil and other chemicals and solvents were of highest grade commercially available.

\section{Induction of renal totoxicity by $\mathrm{CCl} 4$}

Liver toxicity was induced by the intraperitoneal injection of Carbon tetrachloride $\mathrm{CCl} 4$, diluted with distilled water and vector (Olive oil) in the ratio of 1:2:0.5 respectfully. Dosage was determined using $5 \mathrm{ml} / \mathrm{kg}$ body weight, as a standard. Therefore, the specific dosage for each Wister rat was calculated thus:

Milligram Equivalent for renal toxicity induction = $\frac{5 \mathrm{ml} \times \text { weight of rats }(\mathrm{g})}{1000 \mathrm{~g}}$

\section{Determination of Dosage for the Administration of ICW in Experimental Animals. \\ ICW was administered through intragastric injection. The dosage was determined using $100 \mathrm{ml} / \mathrm{kg}$ body weight, as a standard. Therefore the specific dosage for each Wister rat was calculated thus:}

Milligram Equivalent for ICW Administration $=$
$\frac{100 m l \times \text { weightofrat }(g)}{1000 g}$

\section{Experimental Group and Protocol}

The rats were divided randomly into 4 groups comprising 5 rats in each group. They were all fed with the same diet throughout the experimental period. The experimental design is described as follows:

Group I: This group is made up of 5 male rats with weights ranging from $175 \mathrm{~g}-200 \mathrm{~g}$. Rats were fed with rodent pellets and tap water (basal diet), and were injected intraperitoneally on the $7^{\text {th }}$ day of the experiment with olive oil $(0.5 \mathrm{ml} / \mathrm{kg}$ body weight $)$ only.

Group II: This group is made up 5 male rats with weights ranging from $175 \mathrm{~g}-200 \mathrm{~g}$. Rats were fed with rodent pellet, received ICW (100 ml/kg body weight/day) as their sole source of drinking water, and were injected intraperitoneally on the $7^{\text {th }}$ day of the experiment with olive oil $(0.5 \mathrm{ml} / \mathrm{kg}$ body weight). This group served as positive control. The calculated dosage of ICW was given in fragments of 3 times (i.e $8 \mathrm{am}, 1 \mathrm{pm}$, and 5pm) daily; via intragastric injection.

Group III: This group is made up 5 male rats with weights ranging from $175 \mathrm{~g}-200 \mathrm{~g}$. Rats fed basal diet and tap water, and then they were intoxicated via intraperitoneal injection on the $7^{\text {th }}$ day of the experiment with $\mathrm{CCl} 4$ diluted with distilled water and Olive oil, at a ratio of 1:2:0.5 respectively. The dosage given was $5 \mathrm{ml} / \mathrm{kg}$ body weight.

Group IV: This group is made up of 5 male rats with weights ranging from $175 \mathrm{~g}-200 \mathrm{~g}$. Rats fed basal diet and ICW (100 ml/kg body weight/day) as their sole source of drinking water [the calculated dosage of ICW was given in fragments of 3 times (i.e $8 \mathrm{am}, 1 \mathrm{pm}$, and $5 \mathrm{pm}$ ) daily; via intragastric injection], and then they were intoxicated via intraperitoneal injection on the $7^{\text {th }}$ day of the experiment with $\mathrm{CCl} 4$ diluted with distilled water and Olive oil, at a ratio of 1:2:0.5 respectively (the calculated dosage given was $5 \mathrm{ml} / \mathrm{kg}$ body weight).

\section{Collection of Blood Samples}

At the end of the experiment, the animals were fasted overnight prior to the collection of samples. Blood was obtained from the control and experimental animals through Ocular puncture, using capillary tubes. $5 \mathrm{ml}$ of blood samples were collected. The blood obtained was put into EDTA containers and plain blood sample containers. Serum was obtained from the blood and used for analysis.

\section{Biochemical Techniques \\ Chemicals}

Commercially obtained diagnostic kits were used to determine the serum levels of biochemical parameters, as follows: Randox Laboratories Limitedwas used for determination of serum Aspartate aminotranferase (ASP), Alanine aminotranferase (ALT), and Teco Diagnosticswere used for determination of serum Acid phosphatase (ACP).Concentration of the biochemical constituents was calculated according to the manufacturers' instructions. The values obtained were used to analyze the biochemical condition of the experimental animals.

\section{Statistical Data Analysis}

The Results of the Biochemical Parameters were analysed using SPSS. The statistical analysis of variance (ANOVA) test and further test via Bonferroni (ANOVA post-hoc test) for multiple comparisons were performed. Where $\mathrm{p}<0.05$ and Confidence interval (CI) void of zero value were considered statistically significant.

\section{Results}

\section{Biochemical Data Analysis of Blood Serum}

The biochemical activities of AST, ALT and ACP were estimated in serum samples as the liver function biomarkers. These results are given in Table 1. The CCl4 treatment markedly affected the liver specific enzymes. It was found that a significant $(p<0.05)$ increase in serum AST, ALT and ALP activities of $\mathrm{CCl} 4$ treated rats. This result suggests thatthese hepatic biomarkers were elevated in the serum due

\section{Volume 4 Issue 12, December 2015}




\section{International Journal of Science and Research (IJSR) \\ ISSN (Online): 2319-7064 \\ Index Copernicus Value (2013): 6.14 | Impact Factor (2014): 5.611}

to release of the enzymes from damaged liver. However asignificant decrease $(p<0.05)$ was observed in the respective serum activities of rats given Camel milk $+\mathrm{CCl} 4$ compared with $\mathrm{CCl} 4$ treated group. In the other hand, the activities of ACP showed insignificant changes $(\mathrm{p}>0.05)$ in all treated groups.

Table 1: Effects of CCl4 and ICW on serum Aspartate transferase (ASP) activities of liver in rat [Bonferroni(ANOVA posthoc test)Multiple comparison Test output for Group Differences]

\begin{tabular}{|c|c|c|c|c|c|c|}
\hline & \multirow[t]{2}{*}{ Group } & \multirow{2}{*}{$\begin{array}{c}\text { Mean } \\
\text { Difference }\end{array}$} & \multirow[t]{2}{*}{ Std. Error } & \multirow[t]{2}{*}{ P-value } & \multicolumn{2}{|c|}{$95 \%$ Confidence Interval $(\mathrm{CI})$} \\
\hline & & & & & Lower & Upper \\
\hline \multirow[t]{6}{*}{ AST } & Normal \& Positive & $1.09^{*}$ & 0.105 & 0.000 & 0.78 & 1.41 \\
\hline & Normal \& Negative & $-0.70^{*}$ & 0.105 & 0.000 & -1.02 & -0.39 \\
\hline & Normal \& Experimental & $-0.34^{*}$ & 0.105 & 0.031 & -0.65 & -0.02 \\
\hline & Positive \& Negative & $-1.80^{*}$ & 0.105 & 0.000 & -2.11 & -1.48 \\
\hline & Positive \& Experimental & $-1.43^{*}$ & 0.105 & 0.000 & -1.75 & -1.12 \\
\hline & Negative \& Experimental & $0.37^{*}$ & 0.105 & 0.018 & 0.05 & 0.68 \\
\hline
\end{tabular}

Table 2: Effects of CCl4 and ICW on serum Alanine transferase (ALT) activities of liver in ratBonferroni (ANOVA post-hoc test)Multiple comparison Test output for Group Differences

\begin{tabular}{|c|c|c|c|c|c|c|}
\hline & \multirow[t]{2}{*}{ Group } & \multirow{2}{*}{$\begin{array}{c}\text { Mean } \\
\text { Difference }\end{array}$} & \multirow[t]{2}{*}{ Std. Error } & \multirow[t]{2}{*}{ P-value } & \multicolumn{2}{|c|}{$95 \%$ Confidence Interval (CI) } \\
\hline & & & & & Lower & Upper \\
\hline \multirow[t]{6}{*}{ ALT } & Normal \& Positive & $1.71^{*}$ & 0.330 & 0.001 & 0.72 & 2.70 \\
\hline & Normal \& Negative & $-8.61^{*}$ & 0.330 & 0.000 & -9.60 & -7.62 \\
\hline & Normal \& Experimental & $-4.67^{*}$ & 0.330 & 0.000 & -5.66 & -3.68 \\
\hline & Positive \& Negative & $-10.32^{*}$ & 0.330 & 0.000 & -11.31 & -9.33 \\
\hline & Positive \& Experimental & $-6.38^{*}$ & 0.330 & 0.000 & -7.37 & -5.39 \\
\hline & Negative \& Experimental & $3.94^{*}$ & 0.330 & 0.000 & 2.94 & 4.93 \\
\hline
\end{tabular}

Table 3: Effects of CCl4 and ICW on serum Acid phosphatase (ACP) activities of liver in ratBonferroni (ANOVA post-hoc test)Multiple comparison Test output for Group Differences

\begin{tabular}{|c|c|c|c|c|c|c|}
\hline & \multirow[t]{2}{*}{ Group } & \multirow{2}{*}{$\begin{array}{c}\text { Mean } \\
\text { Difference }\end{array}$} & \multirow[t]{2}{*}{ Std. Error } & \multirow[t]{2}{*}{ P-value } & \multicolumn{2}{|c|}{ 95\% Confidence Interval (CI) } \\
\hline & & & & & Lower & Upper \\
\hline \multirow[t]{6}{*}{$\mathrm{ACP}$} & Normal \& Positive & $2.63^{*}$ & 0.193 & 0.000 & 2.05 & 3.21 \\
\hline & Normal \& Negative & $-1.49^{*}$ & 0.193 & 0.000 & -2.07 & -0.91 \\
\hline & Normal \& Experimental & $0.72^{*}$ & 0.193 & 0.011 & 0.14 & 1.29 \\
\hline & Positive \& Negative & $-4.12^{*}$ & 0.193 & 0.000 & -4.70 & -3.54 \\
\hline & Positive \& Experimental & $-1.92^{*}$ & 0.193 & 0.000 & -2.50 & -1.34 \\
\hline & Negative \& Experimental & $2.20^{*}$ & 0.193 & 0.000 & 1.62 & 2.78 \\
\hline
\end{tabular}

\section{Discussion}

In this study, carbon tetrachloride $(\mathrm{CCl} 4)$ treatment of Wister rats in the negative control resulted in elevated serum levels of hepatic enzymes such as; AST, ALT and ACP. These elevations were significant $(p<0.05)$ compared to the normal control as shown in table1-3. The increased serum levels of the hepatic enzymes may de due to the cell membrane and mitochondria damages as a result of $\mathrm{CCl} 4$ induction, thereby resulting to their release into circulation as reported in other studies (26-28). Also, this study confirms the cyto-architectural distortion reported in other studies on hepatoxicity, where cell injury and liver damage occurred after CCl4 (29-35).

Treatment of Wister rats with ICW prior to $\mathrm{CCl} 4$ intoxication in the experimental group, was found to suppress significantly $(\mathrm{p}<0.05)$ the increase of serum AST, ALT and ACP activities induced by $\mathrm{CCl} 4$ treatment in rats. This finding implies that ICW challenge to protect liver tissue from CCl4 injury. Suppression of the elevationof liver enzymes after $\mathrm{CCl} 4$ intoxication may be due to the prevention of the intracellular enzyme leakage from membranes (36). The attenuation of $\mathrm{CCl} 4$ induced liver damage by ICW showed its free radical scavenging and membrane stabilizing activities [23, 37, 38]. However, this can be as a result of its high vitamins and micronutrients content [22, 24,39]. The efficacy of ICW as a hepatoprotective agent has been observed in this study; where it has shown the capacity to reduce the harmful effect, while retaining the hepatic physiology that would have been distorted by a hepatotoxin [40].

\section{Conclusion}

The result of this study showed that ICW caused a protective effect against $\mathrm{CCl} 4$-induced liver damage and as well improved the biochemical parameters. Therefore, ICW may be used as a therapeutic agent to protect against toxic effects of $\mathrm{CCl} 4$ and other chemical agents that may harm the liver.

\section{References}

[1] Moore K. L., \&Dalley, A. F. (210). Clinically oriented anatomy. Philadelphia: Lippincott Williams \& Wilkins.

[2] Lindroos PM, Zarnegar R, Michalopoulos G.K. (1991) Hepatocyte growth factor (hepatopoietin A) rapidly increases in plasma before DNA synthesis and liver regeneration stimulated by partial hepatectomy and 


\section{International Journal of Science and Research (IJSR) \\ ISSN (Online): 2319-7064}

Index Copernicus Value (2013): 6.14 | Impact Factor (2014): 5.611

carbon tetrachloride administration, Hepatology 13:743-50,

[3] Michalopoulos GK, DeFrances M.C (1997) Liver regeneration, Science 276:60-66.

[4] Mandayam S, Jamal MM, Morgan T.R. (2004) Epidemiology of alcoholic liver disease. Semin Liver Dis, 24: 217-32.

[5] Larson AM, Polson J, Fontana RJ, et al. (2005) Acetaminophen-induced acute liver failure: results of a United States multicenter,prospective study. Hepatology, 42: 1364-72.

[6] Rubinstein D. (1962) Epinephrine release and liver glycogen levels after carbon tetrachloride administration. Am J Physiol, 203: 1033-1037

[7] Suja SR, Latha PG, Pushpangadan P, Rajasekharan S. (2002) Aphrodisiac property of Helminthostachyszeylanicain mice. J Trop MedPlants, 3:191-195

[8] Nwokediuko SC, PC Osala, UV Uduma, AK Alaneme, CC Onwuka, C. Mesigo (2013) Pattern of liver disease admissions in a Nigerian tertiary hospital. Niger $\mathrm{J}$ ClinPract. Jul-Sep; 16(3): 339-42. doi: 10: 4103/ 1119 3077.113458.

[9] Mathers CD, Loncar D. Projections of global mortality and burden of disease from 2002 to 2030. PLoS Med; 3: e442.

[10] Williams A.T., Burk R.F. (1990) Carbon tetrachloride hepatotoxicity: an example of three radical-mediated injury. Semin Liver Dis. 10:279-284

[11] Parola, M, Leonarduzz, G, Biasi, F, Albono, M, Biocca, G, Polic, Dianzani, M.U. (1992) Vitamin E dietary Supplementation. Protects against $\mathrm{CCl} 4$ induced chronic liver damage and cirrhosis. Hepatology, 16:1014-1021.

[12] Ulicna, O. Greksak, M., Vancova, O., Zlatos, L., Galbavy, S., Bozek, P., Nakamo, M. (2003): Hepatoprotective effect of Rooibos Tea (Aspalathuslinearig) on $\mathrm{CCl}_{4}$-induced liver damage in rats. Physiol. Res. 52:461-466.

[13] Yan-Jun, L., Jie ping, Y., Zhao-Hong, J. Wang, L. (2004): GingkgoBiloba extract reverses $\mathrm{CCl}_{4}$-induced liver fibrosis in rats. World J. of Gastroenterology, 10:1037-1042.

[14] Agutter P.S., McArdle H.J., McCaldin B. (1976) Evidence for involvement of nuclear envelope nucleoside triphosphatase in nucleocytoplasmic translocation of ribonucleoprotein. Nature, 263: 165167

[15]Li JX, Pang YZ, Tang CS, Li ZQ.( 2004) Protective effect of taurine on hypochlorous acid toxicity to nuclear nucleoside triphosphatase in isolated nuclei from rat liver. World J Gastroenterol, 10: 694-698

[16] Novobrantseva TI, Majeau GR, Amatucci A, Kogan S, Brenner I, Casola S, Shlomchik MJ, Koteliansky V, Hochman PS, Ibraghimov A. (2005) Attenuated liver fibrosis in the absence of B cells. J Clin Invest, 115: 3072-3082.

[17] Yoneyama H, Kai Y, Koyama J, Suzuki K, Kawachi H, Narumi S, Ichida T. (2007) Neutralization of CXCL10 accelerates liver regeneration in carbon tetrachlorideinduced acute liver injury. MedMolMorphol, 40: 191197

[18] Halim AB, el-Ahmady O, Hassab-Allah S, Abdel-Galil F, Hafez Y, Darwish A. (1997) Biochemical effect of antioxidants on lipids and liver function in experimentally-induced liver damage. Ann ClinBiochem.; 34: 656-663

[19] Carbonari KA, Ferreira EA, Rebello JM, Felipe KB, Rossi MH, Felı'cio JD, et al. (2006) Free-radical scavenging by Ourateaparviflora in experimentallyinduced liver injuries. Redox Rep, 11:124-130

[20] Lin H-M, Tseng H-C, Wang C-J, Lin J-J, Lo C-W, Chou F-P. (2008) Hepatoprotective effects of Solanumnigrum Linn extract against CCl4-induced oxidative damage in rats. ChemBiol Interact, 171: 283 293

[21] Alexia Prades, Manuel Dornier, NafissatouDiop, JeanPierre Pain (2012) Coconut water uses, composition and properties: a review. Fruits, vol. 67, p. 87-107. DOI: 10. 1051/fruits/20122002.

[22] United States Department of Agriculture (USDA). National nutrient database for standard reference, Nuts, coconut water, 2008.

[23]Loki AL, Rajamohan T. (2003) Hepatoprotective and antioxidant effect of tender coconut water on $\mathrm{CCl}_{4}$ induced liver injury in rats. Indian $\mathrm{J}$ BiochemBiophy, 40: 354-357.

[24] Shenkin A. The key role of micronutrients (2006). Clinical Nutr;25, 1-13.

[25] United States National Institutes ofHealth Guidelines for Care and Use of Laboratory Animals in Biomedical Research (1985, no. 85-23).

[26] Recknagel RO, Glende JEA, Dolack JA et al (1989) Mechanisms of carbon tetrachloride toxicity. PharmacolTher 43:139-154

[27] Brent JA, Rumack BH (1993) Role of free radicals in toxic hepatic injury II. ClinToxicol 31:173-196

[28] Yan-Jun, L., Jie ping, Y., Zhao-Hong, J. Wang, L., (2004): GingkgoBiloba extract reverses $\mathrm{CCl}_{4}$-induced liver fibrosis in rats. World J. of Gastroenterology 10:1037-1042.

[29] Forni LG, Packer JE, Slater TF et al (1983) Reaction of the trichloromethyl radical and halothane derived peroxy radical with unsaturated fatty acids: a pulse radiolysis study. Chem Boil Interact 85:171-177.

[30] Tribble, DL; Aw, TY; Jones, DP. (1987) The pathophysiological significance of lipid peroxidation in oxidative cell injury. Hepatology 7:377-386.

[31] Wang PY, Kaneko T, Tsukada H et al (1997) Time courses of hepatic injuries induced by chloroform and by carbon tetrachloride: comparison of biochemical and histopathological changes. Arch Toxicol 71(10):638645

[32] Park WH, Lee SK, Kim CH (2005) A Korean herbal medicine, panaxnotoginseng, prevents liver fibrosis and hepatic microvascular dysfunction in rats. Life Sci 76:1675-1690

[33] Mehmetcik G, Ozdemirler G, Koc N et al (2008) Role of carnosine in preventing thioacetamide-induced liver injury in the rat. Peptides 29:425-429

[34] Arıc1 OF, Cetin N (2011) Protective role of ghrelin against carbon tetrachloride $(\mathrm{CCl} 4)$ induced coagulation disturbances in rats. RegulPept 166:139-142

[35] AlthnaianThnaian, Ibrahim Albokhadaim, Sabry M ElBahr (2013) Biochemical and histopathological study in rats intoxicated with carbontetrachloride and treated

\section{Volume 4 Issue 12, December 2015}




\section{International Journal of Science and Research (IJSR) \\ ISSN (Online): 2319-7064}

Index Copernicus Value (2013): 6.14 | Impact Factor (2014): 5.611

with camel milk. SpringerPlus, 2:57. doi:10.1186/21931801-2-57

[36] Thabrew M, Joice PD, Rajatissa W (1987) A comparative study of the efficacy of pavettaindica and osbeckiaoctandra in the treatment of liver dysfunction. Planta Med 53:239-241

[37] Sepaniak S., Forges T., Gerard H., Foliguet B., Bene M.C. and Monnier-Barbarino P. (2006) The Influence of Cigarette Smoking on Human Sperm Quality and DNA Fragmentation. Toxicology, 223, 54-60.

[38] Nair S.V.G. and Rajamohan, T. (2014) The Role of Coconut Water on Nicotine-Induced Reproductive Dysfunction in Experimental Male Rat Model. Food and Nutrition Sciences, 5, 1121-1130.

[39] Effiong GS, Ebong PE, Eyong EU, Uwah AJ, Ekong UE. Amelioration of chloramphenicol induced toxicity in rats by coconut water. J ApplSc Res 2010; 6(4): 331335.

[40] Palanivel MG, Rajkapoor B, Kumar RS et al (2008) Hepatoprotective and antioxidant effect of pisoniaaculeata L. Against CCl4- induced hepatic damage in rats. Sci Pharm 76:203-215 